\title{
A Comparative Function And Position Of English And Indonesian Preposition (Comparative Linguistic)
}

\author{
Lilik Damayanti ${ }^{1)}$, Ramli ${ }^{2}$ \\ ${ }^{1)}$ Politeknik Negeri Balikpapan, Jl. Soekarno Hatta Km. 8 \\ Email: lilik.damayanti@poltekba.ac.id \\ ${ }^{2)}$ Politeknik Negeri Balikpapan, Jl. Soekarno Hatta Km. 8 \\ Email: ramli@poltekba.ac.id
}

\begin{abstract}
Abstrak
Melihat fenomena antara bahasa yang satu dengan lainnya, bisa saja terjadi kesamaan baik di tingkat pengucapan, ejaan, fungsi sintaksis, kategori sintaksis atau bahkan dalam fungsi kelas kata, seperti preposisi. Peneliti berpendapat bahwa ada dua kesamaan berdasarkan fungsi dan posisi yang dapat terjadi antara preposisi bahasa Inggris (in, on, dan at) dan preposisi dalam bahasa Indonesia (di-). Penelitian ini mengambil data dari dua sumber yaitu Daily News dan Kompas. Penelitian ini menggunakan analisis komparatif dengan mengidentifikasi, menunjukkan, dan menggambarkan data dari teks untuk mendukung apa yang peneliti kemukakan, dan menerapkan analisis deskriptif sebagai metode. Hasil penelitian ini menunjukkan bahwa preposisi bahasa Indonesia "di" dapat dibandingkan dengan preposisi bahasa Inggris "in", "on", dan "at" berdasarkan fungsi dan posisi dalam kalimat. Sedangkan fungsi masing-masing dari preposisi dapat diklasifikasikan sebagai preposisi temporal dan preposisi lokatif. Adapun untuk fungsinya sebagai posisi dalam kalimat, dapat disimpulkan bahwa preposisi (in dan on) dapat muncul lebih dari sekali dalam sebuah kalimat, dan dapat saja muncul di awal kalimat, di tengah-tengah kalimat, tetapi sebagian besar muncul di akhir kalimat.
\end{abstract}

Kata kunci: preposisi, lokatif, temporal, kalimat, fungsi, dan posisi.

\begin{abstract}
Taking a look on the phenomena among languages, sometimes the similarities may happen whether in level of pronunciation, spelling, syntactic functions, syntactic categories or even in the function of word class, such as preposition. The researcher argued that there are two similarities based on the function and the position, may occur between the English preposition (in. on. and at) and the Indonesian preposition (di). This research took the data from two sources i.e. Daily News and Kompas. This research describe such a comparative analysis by identifying, showing and describing the evidences from the text to support what the researcher has posited, and applied descriptive analysis as the method. The findings showed that the Indonesian preposition "di" can be compared to the English prepositions "in", "on", and "at" based on the function and the position in the sentence. Concerning on the function, each of the prepositions can be classified as both the temporal preposition and locative preposition. Then, concerning on the position, it can be summed up that the preposition (in and on) can appear more than once in a sentence, moreover each of the preposition can possibly appear in the beginning of the sentence, in the middle of the sentence and mostly appear at the end of the sentences.
\end{abstract}

Keywords: preposition, locative, temporal, sentence, function, and position 


\section{Introduction}

Syntactic categories or word classes will always exist in any languages. Basically, syntactic categories consist of verb, noun, adjective, adverb, preposition, conjunction and determiner. According to Börjars and Burridge (2010) there are eight syntactic categories in English, they are verbs (including auxiliaries), nouns (including pronoun), adjectives, adverbs, prepositions, determiners, conjunctions and interjections. Each of them has its own certain position and function in a sentence. For instance [I saw him in that luxurious room in the middle of night], this sentence consists of noun (I, him, room, middle and night); verb (saw); determiner (that, the, and of); and preposition (in). Another thing that can be seen from this sentence is the word "in" appears twice, and it has little bit different function. Take a look on this phrase [in that luxurious room], here the word "in" shows a particular place, on another hand, on the phrase [in the middle of night] the word "in" refers to a particular time. Furthermore, both phrases are classified as prepositional phrases since each of those phrases are begun with a preposition i.e. "in" and commonly a prepositional phrase consist of preposition and noun. It is supported by Sneddon (1996), moreover Deterding and Poedjosoedarmo (2001) as well argued that a prepositional phrase consists of a preposition that functions as its head followed by a noun phrase (or pronoun).

Concerning on the example above, it means that a preposition can refer to place and time. Besides the preposition "in", there are still other prepositions that have such same function, for instances;

[I put my dirty t-shirt on the floor.] (1)

[I will wear my new t-shirt on Monday] (2)

[I left my dirty t-shirt at home] (3)

[I bought a new red t-shirt at three o'clock yesterday] (4)

Take a look on the sentences (1) and (3), the preposition refers to the place, while the sentences (2) and (4), the preposition refers to time. It means that the preposition "in", "on", and "at" has the same function. It does not only refer to place, but also refer to time.
As we know that any language will have preposition, because a preposition can connect noun (phrase) to another component of sentence therefore it can be assumed that any sentences in any language will need preposition in certain condition, just like Indonesian. A preposition in Indonesia as well has the same function i.e. connecting noun (phrase) to another part in sentence, such as a predicate and a noun phrase. For instances;

[Seorang saksi mata melihatnya berjalan di lorong itu di tengah malam]

There are two prepositional phrases in that sentence because the phrases are begun with a preposition i.e. the word " $d i$ ", they are [di lorong itu] and [di tengah malam]. Taking a look on both phrases, it can be identified that in the phrase [di lorong itu], the preposition " $d i$ " refers to place, while the second phrase, the preposition "di" refers to time. It shows that there is the same phenomenon happens in both English and Indonesian languages.

Furthermore, when the researcher re-expresses four sentences above (1 to 4) into Indonesian, as follow:

[Saya meletakkan kaos kotor saya di (atas) lantai] (5)

[Saya akan memakai kaos baru saya di hari Senin] (6)

[Saya meningalkan kaos kotor saya di rumah] (7)

[Saya membeli sebuah kaos baru berwarna merah di jam tiga kemarin] (8)

From those Indonesian sentences; it is able to be assumed that the preposition " $d i$ " can occur and have the same function as the preposition "on" and "at". Then, the researcher tries once more to re-express the first example above into Indonesian;

English [I saw him in that luxurious room in the middle of night]

Indonesian [Saya melihatnya (berada) di ruang mewah itu di tengah malam] (9)

It can be summed up that the preposition " $d i$ " really has the same function as the preposition "in"; "on" and "at". This phenomenon invited the researcher to dig out more the behavior of those preposition in the sentences of certain 
text. It is in order to find out where the preposition " $d i$ " is placed in the text compared to the preposition "in", "on", and "at" and then to identify whether the preposition "di" has the same function as those three prepositions mentioned above. Searching the text for the source of data so that it will be in line with the purposes of the research, the researcher then decided to choose news in a newspaper such as Kompas (Indonesian Newspaper) and Daily News (American Newspaper). The researcher assumes that a news will consist of informative condition which is described by answering the wh-question, such as when, where, who, what, why and how. Thus, the prepositions discussed will relate to the question of when and where. Besides, both newspapers are the big newspapers which have higher circulation than other newspaper in each its country; therefore the researcher took the news from both, so that it will be ear-eyecatching for the readers.

\section{Method}

Describing the phenomena which are found in the text of news related to the preposition discussed, the researcher employed the descriptive analysis. This research described the position of the preposition " $d i$ " (in Indonesian text) and the preposition "in", "on" and "at" (in English text). Another thing which is described here is the comparative function of those prepositions.

As mentioned above that the data of this research are taken from two newspapers i.e. Kompas and Daily news. This is the title of the news taken from daily news "NYC Marathon: Priscah Jeptoo, Geoffrey Mutai of Kenya win women's and men's titles In wake of Boston Marathon bombing earlier this year, police officers were 'everywhere' on Sunday morning, several race fans told The News." and then this is the title of the news take from Kompas "Pelari Kenya Kuasai Lomba New York City Marathon". Both tell the same thing i.e. the competition of marathon done in New York City. Both are accessed on Monday, November $4^{\text {th }}, 2013$ at 11 a.m.

\section{Discussion}

Every preposition of course will have its own function especially in a sentence, but basically a preposition links noun (phrase) to another part of sentence. Especially, the preposition, "in", "on", and "at", shows or refers to place and time then when these prepositions are compared to the preposition " $d i$ ", it seems that there are two similarities i.e. in position and function. Moreover, when the preposition " $d i$ " substitutes the position of those prepositions, it seems that it is applicable. Therefore, this research tried to find out the same phenomenon as explained above in the text. Hopefully, the researcher could grab it during the analysis.

In order to gain the detail analysis, the researcher parted the analysis into two discussions the first is the comparative function of the preposition and the second is the comparison of position of English (in, on, at) and Indonesian preposition ( $d i)$.

\subsection{The function of the preposition "in", "on", and "at" compared to the preposition ' $d i$ ' in the text}

The researcher has identified fourteen sentences from the news in which the preposition (in, on, at) exist. Those sentences as:

a. The Two Kenyans waved their flag in celebration while thousands cheered in Central Park.

b. Jeptoo, 29, overtook Bronx resident Buzubesh Deba with an impressive final kick and sped across the finish line to thunderous applause, clocking in at $\mathbf{2}$ hours, 25 minutes and 7 seconds for the grueling 26.2-mile race.

c. Deba, 26, finished second for the second straight time, having claimed No. 2 in 2011 as well.

d. Mutai, 32, ran away with the men's crown, powering through the home stretch amid autumn foliage to break the tape at 2:08:24. 
e. Morrison, like others cheering on contenders in the 26.2 -mile road race, ...

f. The 43-year-old marathon, which kicked off in 1970 with just 127 participants, ...

g. McFadden won the women's wheelchair race after also triumphing in the London,

h. No other athlete has won those four races in the same year.

i. ... who was born with a spinal defect and left at a Russian orphanage as a baby, ...

j. ... who beamed back at Hizzoner and the crowd.

k. Ryan Vail of Oregon and Andriana Nelson of Colorado were the first Americans to finish in the men's and women's competitions.

1. On $4^{\text {th }}$ Ave, in Midtown, Eli Zodo, 55, gave air high-fives at sweaty strangers jogging by.

m. Many in the race and alongside were remembering the storm.

n. The Boston tragedy was also on the minds of many runners.

Looking at each sentence above, the researcher noted that each preposition appearing in those sentences mostly refers to place, but there are also the preposition referring to the time. Partly, the researcher stored the detail divisions as written below, they are:

1. [in] - Place:
a. (in celebration),
b. (in Central Park),
c. (in the 26.2-mile road race),
d. (in the London),
e. (in the men's and women's competitions),
f. (in Midtown),
g. (in the race),
[in]-Time:
a. (in 2011),
b. (in 1970),
c. (in the same year)

2. [on] - Place:
a. (on $4^{\text {th }}$ Ave),
b. (on the minds of many runners)

3. [at] - Place:
a. (at a Russian orphanage as a baby)
b. (at Hizzoner and the crowd)

[at] - Time:

a. (at 2 hours, 25 minutes and 7 seconds),

b. (at 2:08:24)

Those parts quoted by the researcher are of course the prepositional phrases. It shows that the findings consist of seventeen prepositional phrases; eleven prepositional phrases refer to place while the rest refer to time. Then, contextually, the researcher tried to insert the meaning of " $d i$ " in each of the prepositional phrase above by translating. It is found that the word " $d i$ " can be used when those sentences are translated into Indonesian. Take on the prepositional phrases [in celebration] and [in the race], according to Indonesian grammatical standar, it will be appropriate to use "pada", so it is [pada perayaan] and [pada balapan itu].

In this research, the researcher found three prepositional phrase that can not be classified as locative and temporal preposition; they are:

[... gave air high-fives at sweaty strangers jogging by].

[... pointed at a participant trotting along in a superman shirt].

It seems that the prepositional phrase [at sweaty strangers jogging by] and [at a participant trotting along] are not referring to time and place, the researcher argues that it is a condition telling that someone do something toward someone else, while in other prepositional phrase [in a superman shirt], it doesn't refers to place and time as well, since it is a condition of someone wearing shirt with the picture of superman on it.

Analyzing the comparative function of the preposition in English and Indonesian grammar, the researcher also tried to find the preposition " $d i$ " in the news published by Kompas. The following are the sentences found by the researcher in the text in which the preposition appearing. Here are the sentences:

a. ... yang akan berlangsung di London,

b. "Saya bermain baik sekali tahun ini, termasuk di awal tahundi Australia Terbuka dan Dubai."

c. ..., saya berada di puncak lagi saat ini." 
d. Ia terpaut sekitar tiga menit di depan Deba ...

e. ...2 24 detik saat memasuki garis finis di Central Park.

f. ... kejadian peledakan bom di lomba Boston ...

g. Polisi disebar di jalur yang dilewati para peserta.

h. ... mengutarakan keinginan berlomba di New York.

i. "Kamu tidak lihat apa yang terjadi di Boston?"

j. Saya sudah di sini saat ini.

k. ... tayangan televisi yang disaksikan 330 juta penonton di seluruh dunia.

Concerning on the preposition, the researcher has identified twelve prepositional phrases of " $d i$ " and based on the function of the prepositional, there is only one prepositional phrase referring to time, while the rest refer to place. In detail, they are as follow:

Place:
a. (di London)
b. (di Australia)
c. (di puncak)
d. (di depan Deba)
e. (di Central Park)
f. (di lomba Boston)
g. (di jalur)
h. (di New York)
i. (di Boston)
j. (di sini)
k. (di seluruh dunia)

Time: (di awal tahun)

Obviously, after detailing each of the prepositional phrases of " $d i$ ", the researcher met the conclusion that this preposition has the same function as the English prepositions (in, on, and at) to show or to refer to the place and the time. Taking a look on several prepositional phrases below:

\footnotetext{
[in Central Park]

[on the minds of many runners]

[at Hizzoner and the crowd]

[di Australia]
}

Each of prepositional phrases above shows that they are able to be classified as the locative preposition (based on Delahunty and Garvey (2010)), since each of them refers to a particular place. Once more, take a look on the next prepositional phrases below:

[in 2011]

[at 2 hours, 25 minutes and 7 seconds]

[di awal tahun]

Unfortunately, the researcher could not find the preposition "on" in the text, therefore the researcher only analyzed the preposition (in, at, and di). It is found that each of the prepositions is followed by a particular range of time. What the researcher meant by "a particular range of time" is that it is including day, month, year, hour, minute and second. So, the researcher laid the classification of these prepositions on Delahunty and Garvey's theory (2010), which indicates that the preposition (in, at, and di) is as temporal preposition.

Even though, the preposition "on" was not found in the text, the researcher argued that the preposition "on" can be involved as the temporal preposition, since usually it is used to refer to certain day, for instance [I will meet her on Friday], this instance can show that the preposition "on" is able to be classified as temporal preposition.

Finally, the researcher can argue that the Indonesian preposition " $d i$ " can be compared to English preposition "in", "on", and "at", and it has been proved by the analysis of the data that each of the preposition discussed in this research can be classified into both locative and temporal preposition and it as well means that each of them has the same function to show or to refer to both place and time.

\subsection{Comparison of position between both English preposition (in, on, and at) and Indonesian preposition (di) in the text}

In order to describe the comparison of the position between the prepositions "in", "on", and "at" and the preposition " $d i$ "; here, the researcher has identified where each of the prepositions are usually placed. Take a look on the sentences below: 
[in]

a. The Two Kenyans waved their flag in celebration while thousands cheered in Central Park.

b. Many in the race and alongside were remembering the storm.

c. The 43-year-old marathon, which kicked off in 1970 with just 127 participants, ...

d. No other athlete has won those four races in the same year.

[at]

a. Jeptoo, 29, overtook Bronx resident Buzubesh Deba with an impressive final kick and sped across the finish line to thunderous applause, clocking in at 2 hours, 25 minutes and 7 seconds for the grueling 26.2-mile race.

b. Mutai, 32, ran away with the men's crown, powering through the home stretch amid autumn foliage to break the tape at 2:08:24.

c. ... who beamed back at Hizzoner and the crowd.

[on]

a. On $4^{\text {th }}$ Ave, in Midtown, Eli Zodo, 55, gave air high-fives at sweaty strangers jogging by.

b. The Boston tragedy was also on the minds of many runners.

[di]

a. "Saya bermain baik sekali tahun ini, termasuk di awal tahundi Australia Terbuka dan Dubai."

b. ..., saya berada di puncak lagi saat ini."

c. ... 24 detik saat memasuki garis finis di Central Park.

d. Polisi disebar di jalur yang dilewati para peserta.

There are three position of the preposition "in" in the sentence; it can be at the end, in the middle and in front. The preposition "in" can occur and appear more than once in a sentence; it depends on the context of the sentence. Then, the positions of the prepositions "at" and "on" are not different from the preposition "in". However, it is not found the preposition "at" used in the beginning of the sentence, while the preposition "on" is only used in the beginning and at the end of sentence.
It is found in the data analyzed that the preposition " $d i$ " appears at the end and in the middle of the sentence. Furthermore, it can as well appear in a sentence more than once.

In short, based on the position in the sentence, both English preposition (in, on, and at) and Indonesian preposition (di) have similarities, such as 1) they, especially "in" and "di" can appear more than once in a sentence; 2) Mostly, each of the preposition appear at the end of sentence; 3 ) it is also possible that each of the preposition can used in front or in the middle of the sentences.

\section{Conclusion}

This research argues that the Indonesian preposition " $d i$ " can be compared to the English prepositions "in", "on", and "at" based on the function and the position in the sentence. Based on the function, each of the prepositions can be classified as both the temporal preposition and locative preposition. Furthermore, based on the position, it can be summed up that the preposition (in and di) can appear more than once in a sentence, then each of the preposition can possibly appear in the beginning of the sentence, in the middle of the sentence and mostly appear at the end of the sentences.

\section{Acknowledgement}

Thisresearch is aimed for people who are concerned and interested on linguistics study. Thank you to P3M in State Polytechnic of Balikpapan to support our research and gives us motivation to increasing our knowledge in case of doing a good research.

\section{Bibliography}

[1] Börjars, Kersti and Burridge, Kate. 2010. Introducing English Grammar (2 $2^{\text {nd }}$ ed). London: Hodder Education

[2] Delahunty, Gerald P. and Garvey, James J. 2010. The English Language from Sound to Sense. Colorado: The WAC Clearinghouse. 
[3] Deterding, david H. and Poedjosoedarmo. Gloria R. 2001. The Grammar of English. Singapore. Prentice Hall.

[4] Greenbaum, Sidney and Nelson, Gerald. 2002. An Introduction to English Grammar $\left(2^{\text {nd }} e d\right)$. London: Pearson Education Limited.

[5] Newson, Mark, et.al. 2006. Basic English Syntax with Exercises.
[6] Sneddon, James Neil. 1996. Indonesian: A Comprehensive Grammar. London: Routledge

[7] http://www.nydailynews.com/newyork/marathon-underway-tightsecurity-article-

1.1505245\#ixzz2jeMFmhmh,

[8] http://www.kompas.com/ Pelari Kenya Kuasai Lomba New York City Marathon/ Tjahjo Sasongko, Senin, 4 November 2013 | 10:46 WIB, 


\title{
Pengaruh Model Pembelajaran SETS (Science, Environment, Technology and Society) Terhadap Hasil Belajar Biologi Siswa Kelas VII SMP Kartika V-1 Balikpapan Tahun Pelajaran 2015/2016
}

\author{
Euis Yuniastuti \\ Fakultas Ilmu Keguruan dan Ilmu Pendidikan, Universitas Tridharma Balikpapan \\ Jalan A.W. Syahrani Nomor 7, Balikpapan
}

\begin{abstract}
This research aims at investigating the influence of SETS learning model to learning outcomes of Biology subject of seventh grade students at SMP Kartika V-1 Balikpapan academic year of 2015/2016. The research population was 147 seventh grade students of SMP Kartika V-1 Balikpapan, from which 38 students were selected as the research samples. Data collection involved literature study, documentations, field observations, and tests. The data were initially analyzed through an estimation of Karl Pearson's product moment correlation coefficient, from which $r_{\text {hit }}\left(r\right.$-calculated) was obtained and further compared with $r_{\text {tab }}(r$ from statistical table) at two significance levels (5 and $1 \%$, respectively). The results showed that $r_{\text {hit }}>r_{\text {tab }}$, meaning that the correlation was significant. The correlation was also categorized "high" since its value fell in the range of 0,600-0,800. Further analysis required t-test to examine the hypothesis. The calculated t-value $\left(t_{\text {hit }}\right)$ was then compared with $t$-value from statistical table at two significance levels (5 and $\left.1 \%\right)$. The results also exhibited that $t_{\text {hit }}>t_{t a b}$, leading to the acceptance of alternative hypothesis $\left(H_{a}\right)$ and the rejection of null hypothesis $\left(H_{0}\right)$. Data analysis eventually concluded that applying SETS as learning model influenced significantly students' learning outcomes in Biology subject. This model fundamentally allows high performing students to develop their skills whilst at the same time students in academic difficulty were assisted in comprehending problems. Lastly it is expected that, through this model, students' learning outcomes of individuals as well as groups will greatly improve.
\end{abstract}

Keywords : SETS Learning Model, Outcomes of Biology

\begin{abstract}
Abstrak
Tujuan yang ingin dicapai dalam penelitian ini ingin mengetahui pengaruh model pembelajaran SETS terhadaphasil belajar Biologi siswa kelas VIISMP Kartika V-1 Balikpapan tahun pelajaran 2015/2016. Populasi dalam penelitian ini adalah seluruh siswa kelas VII SMP Kartika V-1 Balikpapan yang berjumlah 147 orang dan sampelnya adalah 38 siswa. Untuk memperoleh data yang diperlukan dalam penelitian ini penulis menggunakan metode kepustakaan, dokumentasi, observasi dan tes. Setelah data terkumpul penulis mengolahnya dengan menggunakan alat analisis berupa koefisien korelasi product moment dari Karl Pearson dan mendapatkan harga koefisien korelasir ${ }_{\text {hit }}$ dibandingkan kemudian denganr $_{\text {tab }}$ pada taraf signifikansi $5 \%$ dan $1 \%$. Hasil penelitian menunjukkan bahwar ${ }_{\text {hit }}>r_{\text {tab }}$, sehingga dapat disimpulkan bahwa korelasinya signifikan. Apabila data tersebut dihubungkan dengan tabel interpretasi korelasi termasuk kategori korelasi tinggi karena terletak di antara 0,600-0,800. Selanjutnya dalam pengujian hipotesis dengan menggunakan alat uji-t ( $t$-test) diketahui nilai $t_{\text {hit }}$ dan dihubungkan dengan $t_{\text {tab }}$ pada taraf signifikansi $5 \%$ dan $1 \%$ maka didapat hubungan $t_{\text {hit }}>t_{\text {tab. }}$. Hal ini berarti sesuai dengan kriteria pengujian hipotesis apabila $t_{\text {hit }}>t_{\text {tab }}$ maka menerima hipotesis alternatif $\left(H_{a}\right)$ dan menolak hipotesis nol $\left(H_{0}\right)$. Hasil analisis data menyimpulkan bahwa terdapat pengaruh model pembelajaran SETSterhadap hasil belajar Biologi siswa kelas VII SMP Kartika V-1 Balikpapan Tahun Pelajaran 2015/2016. Dengan demikian, siswa yang pandai dapat mengembangkan kemampuan dan ketrampilannya, sedangkan siswa yang lemah akan terbantu dalam memahami permasalahan yang diselesaikan dalam kelompok tersebut. Dengan demikian diharapkan hasil belajar biologi siswa secara individual maupun kelompok juga akan meningkat.
\end{abstract}

Kata Kunci : Model Pembelajaran SETS ,Hasil Belajar Biologi 